\title{
IGOB I 3 I, a novel seed extract of the West African plant Irvingia gabonensis, significantly reduces body weight and improves metabolic parameters in overweight humans in a randomized double-blind placebo controlled investigation Judith L Ngondi ${ }^{1}$, Blanche C Etoundi ${ }^{1}$, Christine B Nyangono ${ }^{1}$, Carl MF Mbofung² and Julius E Oben*1
}

Address: ${ }^{1}$ Laboratory of Nutrition and Nutritional Biochemistry, Faculty of Science, University of Yaounde I, Yaounde, Cameroon and 2Department of Food Science and Nutrition, ENSAI, University of Ngaoundere, BP 686 Ngaoundere, Cameroon

Email: Judith L Ngondi - jlngondi@yahoo.com; Blanche C Etoundi - blancuca@yahoo.fr; Christine B Nyangono - spfernande@yahoo.fr; Carl MF Mbofung - cmbofung@yahoo.com; Julius E Oben* - juliusoben@hotmail.com

* Corresponding author

Published: 2 March 2009

Lipids in Health and Disease 2009, 8:7 doi:10.1 186/1476-5IIX-8-7

This article is available from: http://www.lipidworld.com/content/8/I/7

(c) 2009 Ngondi et al; licensee BioMed Central Ltd.

This is an Open Access article distributed under the terms of the Creative Commons Attribution License (http://creativecommons.org/licenses/by/2.0), which permits unrestricted use, distribution, and reproduction in any medium, provided the original work is properly cited.
Received: 7 January 2009

Accepted: 2 March 2009

\begin{abstract}
Background: A recent in vitro study indicates that IGOBI 3 I, a novel seed extract of the traditional West African food plant Irvingia gabonensis, favorably impacts adipogenesis through a variety of critical metabolic pathways including PPAR gamma, leptin, adiponectin, and glycerol-3 phosphate dehydrogenase. This study was therefore aimed at evaluating the effects of IGOBI 3 I, an extract of Irvingia gabonensis, on body weight and associated metabolic parameters in overweight human volunteers.
\end{abstract}

Methods: The study participants comprised of 102 healthy, overweight and/or obese volunteers (defined as $\mathrm{BMI}>25 \mathrm{~kg} / \mathrm{m}^{2}$ ) randomly divided into two groups. The groups received on a daily basis, either $150 \mathrm{mg}$ of IGOBI3I or matching placebo in a double blinded fashion, 30-60 minutes before lunch and dinner. At baseline, 4, 8 and 10 weeks of the study, subjects were evaluated for changes in anthropometrics and metabolic parameters to include fasting lipids, blood glucose, C-reactive protein, adiponectin, and leptin.

Results: Significant improvements in body weight, body fat, and waist circumference as well as plasma total cholesterol, LDL cholesterol, blood glucose, C-reactive protein, adiponectin and leptin levels were observed in the IGOBI3I group compared with the placebo group.

Conclusion: Irvingia gabonensis administered $150 \mathrm{mg}$ twice daily before meals to overweight and/or obese human volunteers favorably impacts body weight and a variety of parameters characteristic of the metabolic syndrome. This is the first double blind randomized placebo controlled clinical trial regarding the anti-obesity and lipid profile modulating effects of an Irvingia gabonensis extract. The positive clinical results, together with our previously published mechanisms of gene expression modulation related to key metabolic pathways in lipid metabolism, provide impetus for much larger clinical studies. Irvingia gabonensis extract may prove to be a useful tool in dealing with the emerging global epidemics of obesity, hyperlipidemia, insulin resistance, and their co-morbid conditions.

Trial registration: ClinicalTrials.gov NCT00645775 


\section{Background}

Excess adipose tissue increases the workload of the cardiovascular system, adversely alters immune function, and dramatically increases the risk of heart disease, non-insulin-dependent diabetes mellitus, obstructive pulmonary disease, arthritis and a variety of cancers [1]. Although once considered a major health problem isolated to developed countries, obesity is now recognized as a global problem with potentially catastrophic consequences for health economics. In Cameroon, for example, the reported incidence of obesity in urban areas ranges from $17-21 \%$ [2]. This dramatic change reflects the social, nutritional, and lifestyle changes involved in rural-urban migration and the urbanization of rural areas. Worthy of note in this context are the changes from traditional high fibre diets and high-activity lifestyles to diets rich in saturated fat and low in fibre, further compounded by reduction in physical activity levels [3,4]. Insulin resistance, caused by the concomitant, complex interaction of environment (e.g. diet, activity level, elevated body mass, excess visceral adiposity) and genetic factors, is a fundamental pathophysiologic cause of the metabolic syndrome, a recognized risk factor for cardiovascular disease $[5,6]$. Like many other obesity-related conditions, the incidence of the metabolic syndrome is also on the rise in Cameroon [7].

Nutritional management, especially caloric restriction for the purpose of weight reduction, can improve insulin action on target tissues like skeletal muscle, hepatocytes, and peripheral and visceral adipocytes [8,9].

The consumption of Irvingia gabonensis, a fleshy West African fruit, is common in traditional Nigerian and Cameroonian cuisine. Initial observations suggested beneficial changes in metabolic parameters were associated with the high fiber content of Irvingia gabonensis [10]. Results of subsequent analysis suggested that the earlier observations of the beneficial effects of Irvingia gabonensis could not be accounted for by fiber content alone [11]. A recent in vitro study using a validated experimental model (murine 3T3-L1 adipocytes) provides compelling data that Irvingia gabonensis seed extract may inhibit adipogenesis through modulation of PPAR gamma and glycerol-3 phosphate dehydrogenase in addition to beneficial impact upon leptin and adiponectin [12].

The current clinical study was designed to evaluate if the in vitro data could translate into in vivo clinical efficacy in overweight and/or obese human volunteers.

\section{Participants and methods Study population}

Participants for the study were recruited from the city of Yaoundé, Cameroon and surrounding metro region through radio and print media advertisement. Inclusion criteria for study participation mandated: (1) men and women ages 19 to 50 years, in general good health free from significant medical illness that, in the opinion of the investigator, could adversely compromise study participation for any reason; (2) stable body weight (+/- $2 \mathrm{~kg})$ for at least three months prior to study randomization without use of medication known or suspected to affect body weight or appetite; (3) no concomitant or recent (within the past three months) bacterial or seasonal viral infection (e.g. influenza); (4) BMI between $26 \mathrm{~kg} / \mathrm{m}^{2}$ and $40 \mathrm{~kg} / \mathrm{m}^{2}$; (5) no attempts at weight loss through dietary intervention over the three months prior to trial randomization; (6) no participation in a structured weight control program for at least three months prior to study randomization; (7) non-smoker; (8) non-drinkers of sugary fizzy drinks; (9) capability and willingness for multiple blood sampling procedures; and (10) ability to competently understand and sign the consent form.

Based on the above criteria, 120 consenting volunteers (62 males and 58 females) were selected to participate in the study. The protocol used was approved by the Cameroon National Ethics Committee; the study was conducted in accord with the Helsinki Declaration (1983 version).

\section{Study design/intervention}

The study was a randomized, double-blind, placebo-controlled design for 10 weeks. The volunteers were randomly divided into two groups - placebo or IGOB131. The participants consumed either one capsule of placebo or one capsule of IGOB131 (containing $150 \mathrm{mg}$ of Irvingia gabonensis extract) 30-60 minutes before lunch and dinner (BID) throughout the study period.

\section{Test materials}

All test materials were supplied by Gateway Health Alliances, Inc. (Fairfield, CA, USA) in individual packets of capsules. The identical-looking placebo and active formulation capsules contained, respectively, maize-based powder consisting of $150 \mathrm{mg}$ maltodextrin, or $150 \mathrm{mg}$ IGOB131.

\section{Anthropometric measurements}

Height was measured with a locally manufactured wallmounted stadiometer, which was calibrated against the Cameroon's Department of National Security identification scale. Body weight and percent body fat, were assessed using a Tanita ${ }^{\mathrm{TM}}$ BC-418 Segmental Body Composition Analyzer/Scale that uses bio-electrical impedance analysis for body composition analysis. Body mass index (BMI) was calculated using the weight and height measurements. Waist circumference measurements to the nearest $0.1 \mathrm{~cm}$ were taken at the mid-point between the 
bottom rib and the hip bone, without restrictive garments using a flexible non expandable tape measure.

\section{Dietary Intake}

Three days before the collection of baseline measurements and three times during the trial, dietary intake of subjects was evaluated by a qualified dietician. Energy and protein intakes were calculated using standard food composition tables based upon the 3-day food intake record.

No major dietary intervention or formal physical activity program was instituted during the course of the study; participants were instructed to maintain the current level of physical activity prior to study randomization during the course of the study.

\section{Sample collection}

Fasting blood samples ( $5 \mathrm{ml}$ of blood) were collected at baseline, and at 4, 8, and 10 weeks. Serum obtained from each blood sample was split into multiple $500 \mu \mathrm{l}$ aliquots and stored at $-20^{\circ} \mathrm{C}$ until needed for the measurement of total cholesterol, LDL cholesterol, fasting blood glucose, C-reactive protein, adiponectin, and leptin levels.

\section{Analytical methods}

Determination of glucose in blood using glucose oxidase with an alternative oxygen receptor was adopted for this study [13]. Serum total cholesterol was assayed by the cholesterol oxidase method [14] while triglycerides as well as serum glucose levels were assayed following the method described by Buccolo \& David [15]. Quantitative determinations of C-reactive protein (CRP) was assessed using a high sensitivity immunoassay (Oxis International, Foster City, CA. USA) while serum leptin was determined in duplicate using an enzyme-linked immunosorbent assay (ELISA) (Diagnostic Systems Laboratory, Webster, TX. USA) technique within the same assay, with an intraassay variance of $3.2 \%$. Serum adiponectin was measured in duplicate using an enzyme immunoassay (APLCO Diagnostics, Salem, NH. USA) within the same assay. Intra-assay variance was $\leq 5 \%$.

\section{Statistical analysis}

Statistical analyses (Student's t-test and ANOVA) were performed using the Statistical Package for the Social Sciences (SPSS) software. Graphical representations of relative changes in measured variables were performed using Sigma Plot statistical package.

\section{Results}

The 120 volunteers (mean age 34, range 19-50) were divided into 2 groups, with 60 randomly assigned to placebo and 60 to IGOB131 (active). Of these initial 120 volunteers, 102 completed the 10 week study; 50 from the placebo group, and 52 from the IGOB131 group. Eighteen volunteers [placebo $(\mathrm{n}=12)$ and IGOB131 $(\mathrm{n}=6)$ ] dropped out of the study for the following reasons - not experiencing rapid weight loss $(\mathrm{n}=10)$; influenza attack $(\mathrm{n}=3)$; dryness of mouth $(\mathrm{n}=3)$; no reason given $(\mathrm{n}=2)$.

\section{Food Intake}

The mean daily energy intake in the IGOB131 group was $2767 \pm 187 \mathrm{kcal}$ of which $56 \%$ was from carbohydrate, $29 \%$ from protein, and $15 \%$ from fat. In the placebo group, the mean daily energy intake was $3156 \pm 185 \mathrm{kcal}$ of which $56 \%$ was from carbohydrate, $29 \%$ was from protein, and $15 \%$ was from fat. Seven-day dietary and activity assessment of the subjects at baseline showed similar food intake habits and energy levels.

\section{Body weight, waist size and body fat}

Baseline characteristics of the two groups were wellmatched and without significant differences at baseline (Table 1). There were no significant differences in the baseline body weight, waist circumference and serum leptin measurements between the placebo and experimental group (Table 1). However, by the tenth week, significant differences were observed between the placebo and experimental intervention groups, respectively, for body weight (95.7 kg vs. $85.1 \mathrm{~kg}$, respectively, p < 0.01), waist circumference $(101.1 \mathrm{~cm}$ vs. $88.1 \mathrm{~cm}$, respectively, p < 0.05$)$. Body fat decreased over time in both groups but the experimental group lost significantly more body fat $(6.3 \%$, p < 0.05 ) compared to the placebo group (1.9\%) (Table 1).

When corrected for placebo response, the pattern of relative changes in weight and waist circumference was found to be different between the two groups, consistent with a difference in response to the intake of the extract (Figure 1).

\section{Total and LDL cholesterol, C-reactive proteins, leptin}

These variables decreased from baseline, though at different rates and magnitudes associated with duration of the study, with the experimental group showing statistically significant changes compared with the placebo group at week-10 (Table 1).

While baseline levels of serum lipids were similar in the two groups, significant differences were observed between the two as the study progressed with the experimental group showing progressively greater improvement. At week-10, significant differences were observed for total cholesterol (placebo: $142.5 \mathrm{mg} / \mathrm{dl}$ vs. IGOB131: 111.9 $\mathrm{mg} / \mathrm{dl}, \mathrm{p}<0.05$ ) and LDL cholesterol (placebo: $77.7 \mathrm{mg} /$ $\mathrm{dl}$ vs IGO131: $59.77 \mathrm{mg} / \mathrm{dl}, \mathrm{p}<0.01$ ). Compared to baseline values, total cholesterol decreased by $1.9 \%$ in the placebo group as opposed to $26.2 \%$ for the IGOB131 group while LDL cholesterol levels fell by $4.8 \%$ in the placebo compared to $27.3 \%$ in the IGOB131 group. Correcting for 
Table I: Changes* in body weight, waist, leptin, fat, total cholesterol, LDL cholesterol, glucose and adiponectin measurements in the course of the study.

\begin{tabular}{|c|c|c|c|c|c|c|}
\hline \multirow[b]{2}{*}{ Variables } & \multirow[b]{2}{*}{ Group } & \multicolumn{5}{|c|}{ Time (weeks) } \\
\hline & & Base line & 4 & 8 & 10 & Over change \\
\hline \multirow{2}{*}{ Weight (Kg) } & Placebo & $96.4 \pm 12.3$ & $95.8 \pm 8.2$ & $95.1 \pm 10.6$ & $95.7 \pm 15.2$ & -0.7 \\
\hline & $|G O B| 3 \mid$ & $97.9 \pm 9.1$ & $94.3 \pm 5.5$ a & $89.7 \pm 4.7$ a & $85.1 \pm 3.1^{b}$ & -12.8 \\
\hline \multirow[t]{2}{*}{ Waist (cm) } & Placebo & $106.4 \pm 10.8$ & $102.7 \pm 10.6$ & $101.1 \pm 14.8$ & $101.1 \pm 15.8^{b}$ & -5.3 \\
\hline & $|G O B| 3 \mid$ & $105.1 \pm 6.3$ & $98.0 \pm 8.4^{a}$ & $90.1 \pm 8.70^{a}$ & $88.1 \pm 7.6$ & -16.19 \\
\hline \multirow{2}{*}{ Leptin (ng/ml) } & Placebo & $31.3 \pm 1.8$ & $29.4 \pm 1.4$ & $28.1 \pm 1.8$ & $28.4 \pm 1.8$ & -2.9 \\
\hline & $|G O B| 3 \mid$ & $32.9 \pm 1.6$ & $18.1 \pm 1.3^{\mathrm{a}}$ & $16.8 \pm 1.2^{\mathrm{a}}$ & $16.9 \pm 1.3^{b}$ & -16.0 \\
\hline \multirow[t]{2}{*}{ Fat (\%) } & Placebo & $34.7 \pm 8.6$ & $33.31 \pm 10.9$ & $32.9 \pm 11.9$ & $32.7 \pm 15.7$ & -1.99 \\
\hline & $|G O B| 3 \mid$ & $34.2 \pm 7.9$ & $31.6 \pm 5.4^{a}$ & $28.2 \pm 6.6^{\mathrm{a}}$ & $27.9 \pm 5.5^{\mathrm{a}}$ & -6.3 \\
\hline \multirow{2}{*}{ LDL cholesterol (mg/dL) } & Placebo & $77.4 \pm 9.2$ & $76.5 \pm 8.9$ & $74.1 \pm 9.3$ & $73.7 \pm 8.3$ & -3.75 \\
\hline & $|G O B| 3 \mid$ & $82.2 \pm 8.1$ & $71.8 \pm 5.9 \mathrm{~b}$ & $64.7 \pm 8.9 b$ & $59.8 \pm 5.0^{b}$ & -22.44 \\
\hline \multirow[t]{2}{*}{ Total cholesterol (mg/dL) } & Placebo & $145.2 \pm 22.4$ & $143.9 \pm 12.2$ & $142.1 \pm 13.6$ & $142.4 \pm 12.1$ & -2.8 \\
\hline & $|G O B| 3 \mid$ & $151.7 \pm 18.5$ & $133.7 \pm 16.6^{a}$ & $120.1 \pm 11.9 \mathrm{a}$ & $111.9 \pm 5.8^{a}$ & -39.8 \\
\hline \multirow[t]{2}{*}{ C-reactive protein (mg/L) } & Placebo & $1.46 \pm 0.05$ & $1.46 \pm 0.04$ & $1.445 \pm 0.03$ & $1.455 \pm 0.05$ & -0.01 \\
\hline & $|G O B| 3 \mid$ & $1.49 \pm 0.04 \mathrm{I}$ & $0.91 \pm 0.05^{a}$ & $0.7 \mathrm{I} \pm 0.04 \mathrm{~b}$ & $0.72 \pm 0.05^{b}$ & -0.78 \\
\hline \multirow[t]{2}{*}{ Glucose (mg/dL) } & Placebo & $81.4 \pm 9.6$ & $79.5 \pm 10.1$ & $77.8 \pm 9.4$ & $77.1 \pm 7.8$ & -4.3 \\
\hline & $|G O B| 3 \mid$ & $85.55 \pm 5.59$ & $76.6 \pm 10.3^{a}$ & $68.7 \pm 9.3^{a}$ & $66.3 \pm 4.9 \mathrm{a}$ & -19.3 \\
\hline \multirow[t]{2}{*}{ Adiponectin (mg/L) } & Placebo & $12.1 \pm 3.2$ & $15.2 \pm 3.5$ & $14.6 \pm 3.5$ & $14.94 \pm 3.9$ & +2.8 \\
\hline & IGOBI3| & $12.2 \pm 3.0$ & $24.8 \pm 3.8^{a}$ & $31.0 \pm 4.0^{b}$ & $31.6 \pm 3.9 \mathrm{a}$ & +19.4 \\
\hline
\end{tabular}

a $\mathrm{P}<0.05 ;$ b $\mathrm{P}<0.01$ compared with Placebo

placebo values, the relative change in the total cholesterol and LDL cholesterol was observed to follow a similar pattern (Figure 2) in the experimental group, suggesting a similar response mechanism to IGOB131 intake.

Like in the case of the other parameters measured, C-reactive protein and leptin levels decreased over time in both groups. The rate of decrease was however accelerated in the IGOB131 relative to the placebo-group. Serum levels of CRP fell by $1.2 \%$ in the placebo group as opposed to $52.0 \%$ in the experimental group relative to baseline. On the other hand, leptin levels decreased by $9.3 \%$ in the placebo group compared to a $48.6 \%$ in the IGOB131 group over the 10-week experimental period.

\section{Fasting blood glucose levels}

Blood glucose levels in the experimental group $(85.6 \mathrm{mg} /$ $\mathrm{dl} \pm 5.6 \mathrm{mg} / \mathrm{dl})$ and in the placebo group $(81.4 \pm 9.6 \mathrm{mg} /$ $\mathrm{dl})$ were similar at baseline but decreased to significantly different levels $(\mathrm{P}<0.05)$ at week-10 of the study (Table $1)$. In relative terms, decreases in placebo and treatment groups were $5.3 \%$ vs. $22.5 \%$, respectively (Figure 3). Corrected for the placebo values, the changes in blood glucose levels were similar to that of lipids (Figure 2).

\section{Adiponectin levels}

Baseline serum adiponectin levels were comparable between the two groups (placebo: $12.1 \mathrm{mg} / \mathrm{l} \pm 3.21 \mathrm{mg} / \mathrm{l}$; IGOB131: $12.16 \mathrm{mg} / \mathrm{l} \pm 3.04 \mathrm{mg} / \mathrm{l}$ ), but increased with time (Table 1). By week-10 of the study adiponectin levels in the placebo group increased by $23.4 \%$ compared to $159.8 \%$ in the experimental group. Corrected for placebo values, the rate of increase in serum adiponectin levels in IGOB131 group followed an exponential curve (Figure 4).

\section{Adverse events}

Treatment of overweight and obese subjects with IGOB131 was well-tolerated. Adverse events with an incidence $>n=3$ included headache $(n=5)$, sleep difficulty ( $n$ $=6)$, and intestinal flatulence $(n=6)$. The incidence of all reported side effects was similar in the placebo group as well as in the treatment group. 


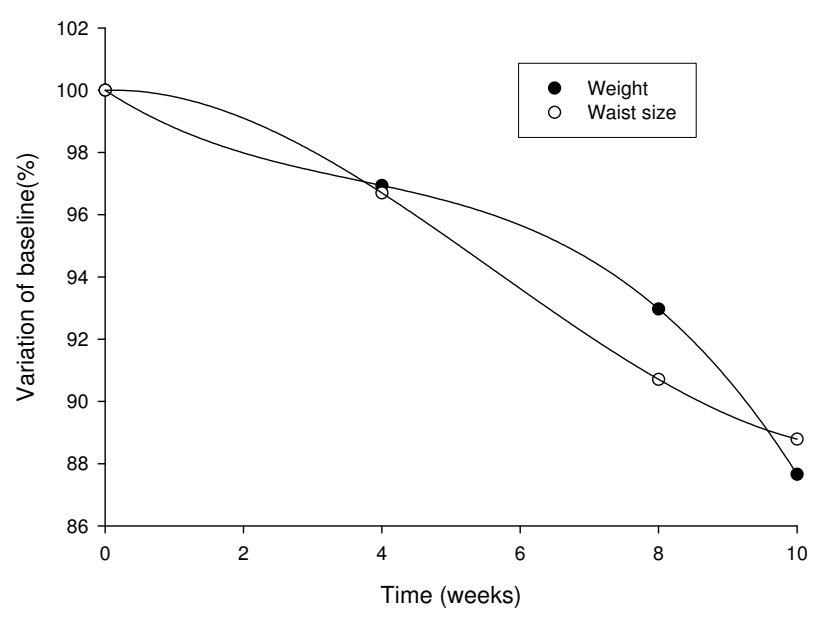

\section{Figure I}

Changes in body weight and waist circumference measurements in IGOB I 3 I group corrected for placebo values.

\section{Discussion}

The present study suggests that IGOB131, a seed extract of Irvingia gabonensis, safely and significantly reduces body weight in overweight and/or obese subjects, and has a favorable impact upon a variety of other metabolic parameters. The current clinical study shows IGOB131 administration is associated with increases in plasma adiponectin levels and decreases in leptin and CRP levels in comparison with the placebo group. These observations support the results of a recent in vitro study [12] which

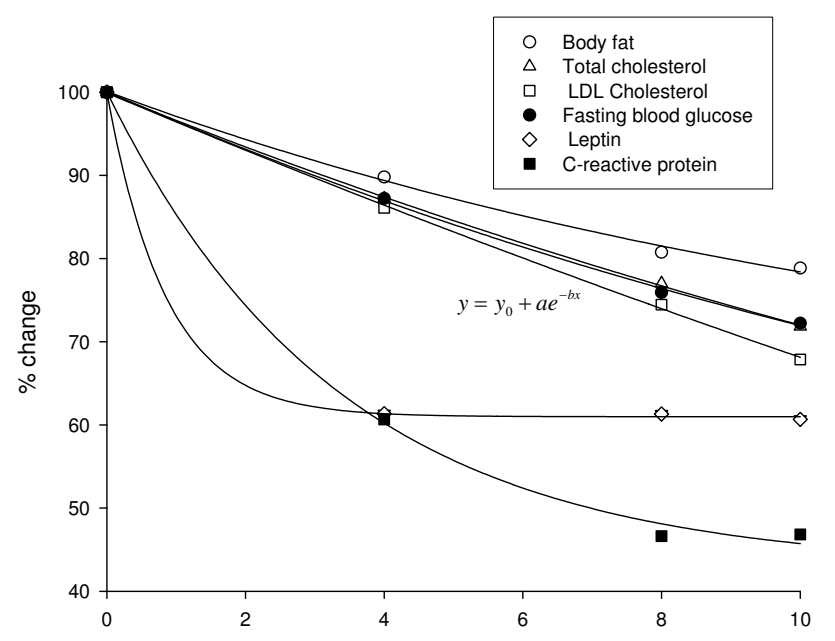

Figure 2

Changes in measured characteristics in IGOB I 3 I group corrected for placebo values. suggests a favorable impact upon adipogenesis associated with IGOB131.

Insulin resistance is the hallmark of the metabolic syndrome and is strongly associated with excess adiposity [16]. A variety of adipocyte-derived biologically active molecules have been identified, including leptin, resistin, TNF- $\alpha$, and IL-6, that may contribute to obesity-linked metabolic abnormalities [17]. Since plasma leptin levels are closely correlated with the level of adipose tissue [18], the decreases in plasma leptin level associated with IGOB131 treatment may be attributable to the decrease of adipose tissue induced as a consequence of weight loss.

According to McTernan et al. [17], adipose tissue plays a prominent role in the clinical expression of metabolic syndrome, most likely mediated by the increased release and peripheral tissue action of non-esterified fatty acids and by the dysregulated production of adipocyte-secreted proteins, including leptin, adiponectin, resistin, TNF- $\alpha$, and IL-6. Adiponectin, known to correlate with endothelial function and vascular health, is exclusively expressed in adipose tissue and abundant in human plasma, and appears to be decreased in individuals with obesity and type 2 diabetes, risk factors for atherosclerosis[19].

The observation of a significant weight loss, as well as an increase in adiponectin is consistent with earlier reports in the literature observing an association between weight loss and an increase in adiponectin levels [20].

IGOB131 is relatively rich in plant-derived protein and antioxidants. A study by Baum et al, [21] had earlier shown a reduction of both total cholesterol and triglycerides levels in a hypercholesterolemic man who was fed a plant protein diet. Other studies have shown metabolic syndrome-preventive activity of antioxidant components (e.g. vitamin C, polyphenols). A number of polyphenols such as epigallocatechin gallate have anti-obesity activity and may improve metabolic disorders via modulation of adipokines and growth factors, including metabolic improvement of leptin function [22-24]. Although the active principles of IGOB131 have not yet been fully identified, it is possible that it contains some of the above mentioned compounds.

In conclusion, Irvingia gabonensis extract administered twice a day to healthy, overweight and obese individuals resulted in both weight reduction (body weight, body fat, waist size) and an improvement in metabolic parameters associated with insulin resistance. The current results suggest that IGOB131 may be a helpful adjunct in the management of overweight and/or obesity, supporting previous suggestions from our laboratory [25]. 


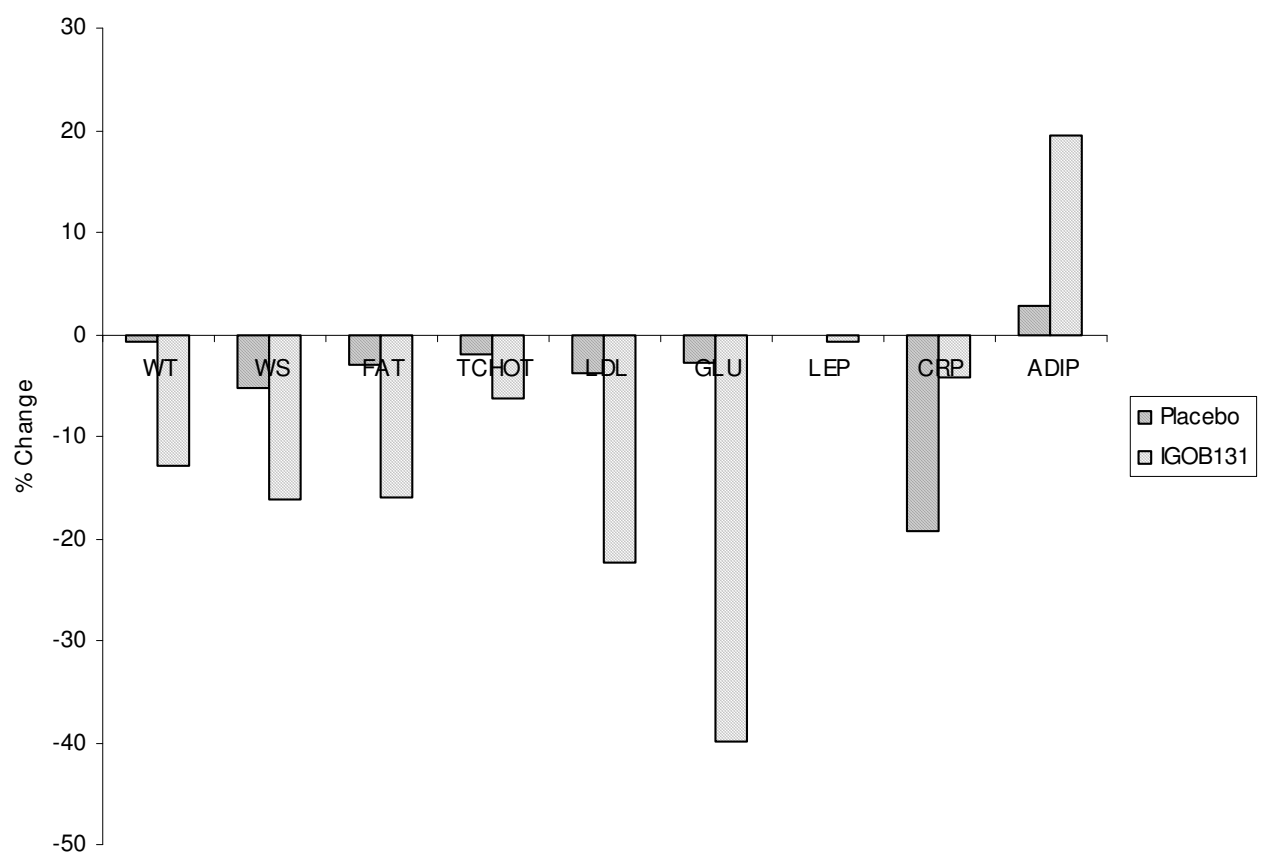

Figure 3

Percentage decrease in body weight (WT), Waist size (WS), Fat (FAT), Total Cholesterol (TCHOL), LDL cholesterol (LDL), Glucose (GLU), Leptin (LEP), C-reactive protein (CRP) and Adiponectin (ADIP) after I0 weeks of use of extract IGOI 3 I.

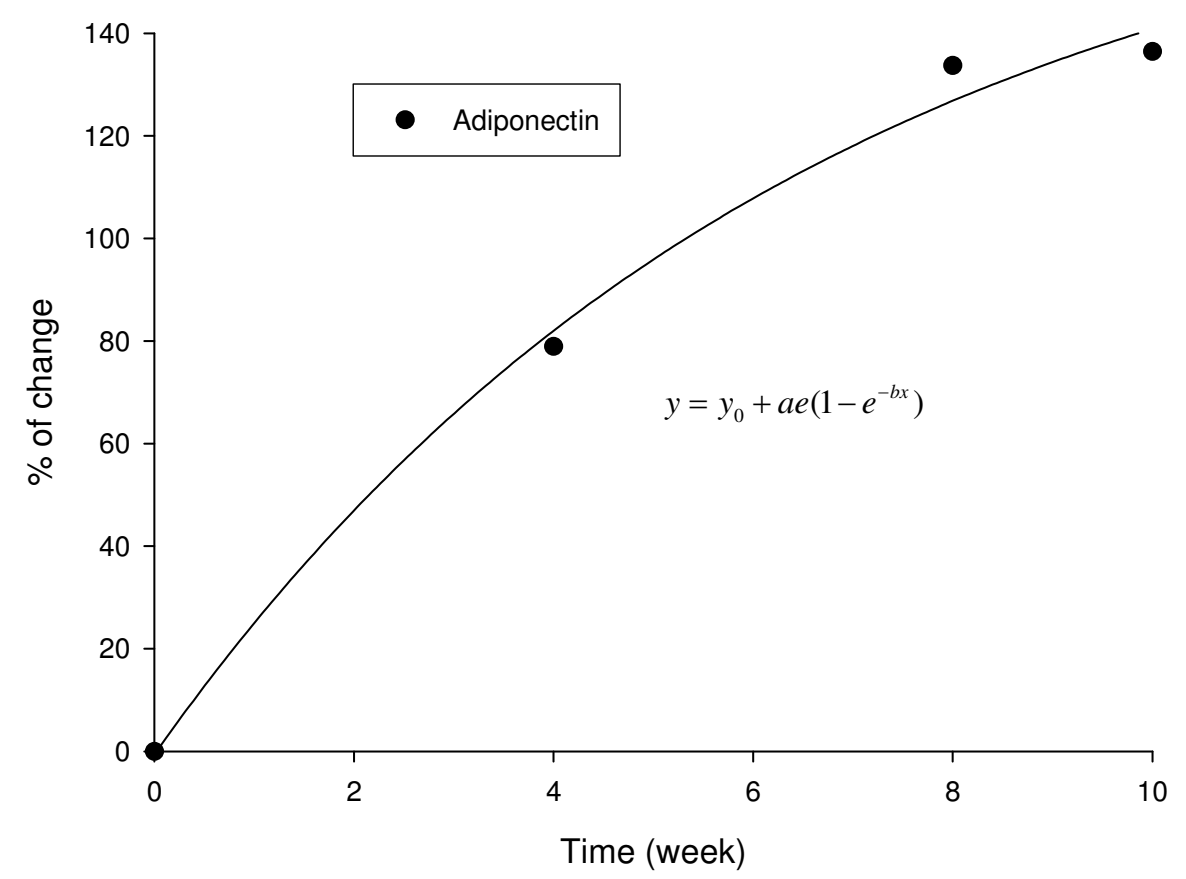

Figure 4

Changes in the adiponectin levels in IGOB I 3 I group corrected for placebo. 


\section{Competing interests}

Part of the funds for carrying out this study was provided by Gateway Health Alliances Inc., through their "Encouragement of Research in developing countries Initiative".

\section{Authors' contributions}

JEO conceived, designed and coordinated the work, as well as prepared the manuscript; CMFM was involved in the co-design of the work as well as the draft of the manuscript. JLN carried out analytical work, BCE carried out analytical work and contributed in drafting the manuscript; CBN carried out analytical and statistical analysis. All authors read and approved the final manuscript.

\section{Acknowledgements}

The LNNB is grateful to Gateway Health Alliances Inc. (Fairfield, California, USA) for preparing and supplying the Irvingia gabonensis extract (IGOBI3I). The authors are extremely grateful to Dr. Kenneth Blum of Wake Forest University School of Medicine, North Carolina for reviewing this article.

\section{References}

I. Conway B, Rene A: Obesity as a disease: no lightweight matter. Obes Rev 2004, 3:145-5I.

2. Pasquet P, Temgoua LS, Melaman SF, Froment A, Rikong AH: Prevalence of obesity and overweight for urban adults in Cameroon. Annal of Human Biology 2003, 30:55I-562.

3. Caballero B: Introduction Symposium. Obesity in developing countries, Biological and ecological factors. J Nutr 200I, | 3 I (3):866-870.

4. Lee K, Sobal J: Socio-economic, dietary, activity, nutrition and body weight transitions in South Korea. Public Health Nutr 2003, 6(7):665-674.

5. Reaven GM: Role of insulin resistance in human disease. Diabetes 1989, 37:1595-1607.

6. NCEP - National Cholesterol Education Program: Expert Panel on Detection, Evaluation, and Treatment of High Blood Cholesterol in Adults (Adult Treatment Panel III) final report. Circulation 2002, 106:3|43-3121.

7. Mandob DE, Ngondi JL, Fomekong GI, Agbor GA, Oben JE: Prediction and prevalence of metabolic syndrome in overweight and obese subjects in Cameroon. International $J$ of Biomedical and Pharmaceutical Sciences 2008, 2:1 17-121.

8. Goodpaster BH, Kelley DE, Wing RR, Meier A, Thaete FL: Effects of weight loss on regional fat distribution and insulin sensitivity in obesity. Diabetes 1999, 48:839-847.

9. Knowler WC, Barrett-Connor E, Fowler SE, Hamman RF, Lachin JM, Walker EA, Nathan DM: Reduction in the incidence of type 2 diabetes with lifestyle intervention or metformin. $N$ Engl J Med 2002, 346:393-403.

10. Ngondi J, Oben J, Minka R: The effect of Irvingia gabonensis seeds on body weight and blod lipids of obese subjects in Cameroon. Lipids in Health \& Disease 2005, 4:12.

II. Ngondi JL, Djiotsa EJ, Fossouo Z, Oben J: Hypoglycaemic effect of the methanol extract of Irvingia gabonensis seeds on streptozotocin diabetic rates. Afr J Trad Cam 2006, 3(4):74-77.

12. Oben J, Ngondi JL, Blum K: Inhibition of Irvingigia gabonensis seed extract $(O B|3|)$ on adipogenesis as mediated via down regulation of the PPARy and Leptin genes and up-regulation of the adiponectic gene. Lipids in Health and Disease 2008, 7:44.

13. Trinder P: Determination of glucose in blood using glucose oxidase with an alternative oxygen acceptor. Ann Clin Biochem 1969, 6:24.

14. Richmond W: Preparation and properties of a cholesterol oxidase from Nocardia sp. and its application to the enzymatic assay of total cholesterol in serum. Clin Chem 1973, 19:1350-1356.

15. Buccolo G, David H: Quantitative determination of serum triglycerides by the use of enzymes. Clin Chem 1973, 19:476-482.
16. Maison P, Byrne CD, Hales CN, Day NE, Wareham NJ: Do different dimensions of the metabolic syndrome change together over time? Evidence supporting obesity as the central feature. Diabetes Care 200I, 24:1758-1763.

17. McTernan CL, McTernan PG, Harte AL, Levick PL, Barnett AH, Kumar S: Resistin, central obesity, and type 2 diabetes. Lancet 2002, 359:46-47.

18. Friedman JM, Halaas JL: Leptin and the regulation of body weight in mammals. Nature 1998, 395:763-770.

19. Weyer C, Funahashi T, Tanaka S, Hotta K, Matsuzawa Y, Pratley RE, Tataranni PA: Hypoadiponectinemia in obesity and type 2 diabetes, close association with insulin resistance and hyperinsulinemia. J Clin Endocrinol Metab 200I, 86: 1930-1935.

20. Yang WS, Lee WJ, Funahashi T, Tanaka S, Matsuzawa Y, Chao CL, Chen CL, Tai TY, Chuang LM: Weight reduction increases plasma levels of an adipose-derived anti-inflammatory protein, adiponectin. J Clin Endocrinol Metab 200I, 86:3815-3819.

21. Baum JA, Teng H, Erdman JW Jr, Weigel RM, Klein BP, Persky VW, Freels S, Surya P, Bakhit RM, Ramos E, Shay NF, Potter SM: Longterm intake of soy protein improves blood lipid profiles and increases mononuclear cell low-density-lipoprotein receptor messenger RNA in hypercholesterolemic, postmenopausal women. Am I Clin Nutr 1998, 68:545-55।.

22. Kao YH, Hiipakka RA, Liao S: Modulation of obesity by a green tea catechin. Am J Clin Nutr 2000, 72(5): I232-I234.

23. Okamoto $Y$, Kihara S, Ouchi N, Nishida M, Arita $Y$, Kumada M, Ohashi K, Sakai N, Shimomura I, Kobayashi H, Terasaka N, Inaba T, Funahashi T, Matsuzawa Y: Adiponectin reduces atherosclerosis in apolipoprotein E-deficient mice. Circulation 2002, 106:2767-2770.

24. Yamauchi T, Kamon J, Minokoshi Y, Ito Y, Waki H, Uchida S, Yamashita S, Noda M, Kita S, Ueki K, Eto K, Akanuma Y, Froguel P, Foufelle F, Ferre P, Carling D, Kimura S, Nagai R, Kahn BB, Kadowaki T: Adiponectin stimulates glucose utilization and fatty-acid oxidation by activating AMP-activated protein kinase. Nat Med 2002, 8: $1288-1295$.

25. Ngondi JL, Fossouo Z, Djiotsa EJ, Oben J: Glycaemic variations after administration of Irvingia gabonensis seeds fractions in normoglycemic rats. Afri J Trad Cam 2006, 4:94-I0.

Publish with Bio Med Central and every scientist can read your work free of charge

"BioMed Central will be the most significant development for disseminating the results of biomedical research in our lifetime. "

Sir Paul Nurse, Cancer Research UK

Your research papers will be:

- available free of charge to the entire biomedical community

- peer reviewed and published immediately upon acceptance

- cited in PubMed and archived on PubMed Central

- yours - you keep the copyright 